Orissa Journal of Commerce

Vol. 42, Issue 1, Jan-March 2021

ISSN: 0974-8482

(C) OJC India. All Right Reserved

URL : www.ojcoca.org

DOI: https://doi.org/10.54063/ojc.2021.v42i01.06

\title{
Tax Collection Efficiency of Indian States: A DEA Approach
}

\author{
Pitabas Biswal ${ }^{1}$ and Himanshu Sekhar Rout ${ }^{2 *}$ \\ ${ }^{1}$ Research Scholar, Department of Analytical and Applied Economics, Utkal University, Bhubaneswar, Odisha. \\ E-mail:pitabasb162@gmail.com \\ ${ }^{2}$ Reader, Department of Analytical and Applied Economics \& RUS A Centre of Excellence in Public Policy and Governance, \\ Utkal University,Bhubaneswar, Odisha.E-mail: hsrout@utkaluniversity.ac.in \\ ${ }^{*}$ Corresponding Author
}

To cite this paper

Biswal, P., \& Rout, H. S. (2021)

Tax Collection Efficiency of Indian States: A DEA Approach.

Orissa Journal of Commerce. 42(1), 78-91.

\section{Keywords}

Data envelopment analysis, Tax collection efficiency, Goods service taxes, Household income

JEL Classification H2, H6, H21

\begin{abstract}
The study has measured the tax collection efficiency of Indian states in pre-GST era and tried to find out solutions to tackle inefficiency. In order to estimate relative efficiency score, input-oriented data envelopment analysis (DEA) model has been applied for seventeen general category states (GCS) and eleven special category states (SCS) separately. The study has found that first, GCS are $54 \%$ and SCS are $72 \%$ relative efficient. Second, there is a positive and significant correlation between efficiency score and tax collection per Indian rupee expenditure. Third, efficiency score has positive correlation with literacy rate and negative correlation with percentage of household experienced corruption. Therefore, the study has fixed a target for the new tax regime to achieve $100 \%$ tax collection efficiency in use of inputs by using extensive Information and Communication Technology (ICT) for handling corruption in one hand and by introducing tax education at high school level in order to enhance public awareness about taxation on the other hand.
\end{abstract}

\section{Introduction}

Taxation is considered as an important part of public administration and efficiency is considered as one of its important cannons. In the present world, the importance of efficiency in tax collection is increasing day by day because of increasing financial pressure. The pressure is the result of increasing state activities and at the same time, increased tax rates are strictly opposed as it could depreciate economic growth (Chiumia and Simwake, 2012). Huge deficits and mounting debts are the major challenges of the fiscal policy of both developed and developing countries. This has "added considerable pressure to the revenue collections agencies on at least two fronts: (i) pressure to increase tax collections, which under current tax laws can only occur through increased enforcement and (ii) the fiscal strain that is forcing cutbacks in resources allocated to the tax agencies" (Alm and Dunchan, 2014).

As a developing nation, India is not an exception to experiencing such fiscal pressure. India is a federation of states and in such a system, when the finance of the central government comes under pressure, the central government cuts back the planned transfer to the state government by which the 
interests of the state government are affected. The Fiscal Responsibility and Budget Management (FRBM) Act 2003 was mandated with the objective of bringing revenue surplus and fiscal deficit to three percent of gross state domestic product (GSDP). Therefore, each and every state government on their part has been making attempts to minimize fiscal and revenue deficit to have fiscal discipline" (Acharya and Sahoo, 2017). Under such circumstances, it is not favorable to cut the expenditure as it can affect the developmental process negatively. Therefore, efficient allocation of resources is a suitable way to tackle the unfavorable situation. Increasing tax collection efficiency of each Indian state could somehow offset the increment of fiscal pressure, whilst reducing the incidence of fiscal fraud. This is because tax collection per Indian rupee expenditure in some states is very low in comparison to other states in India, which is highlighted in Figure 1 and Figure 2. The horizontal axis shows name of different states and the vertical axis measures tax collection per rupee expenditure.

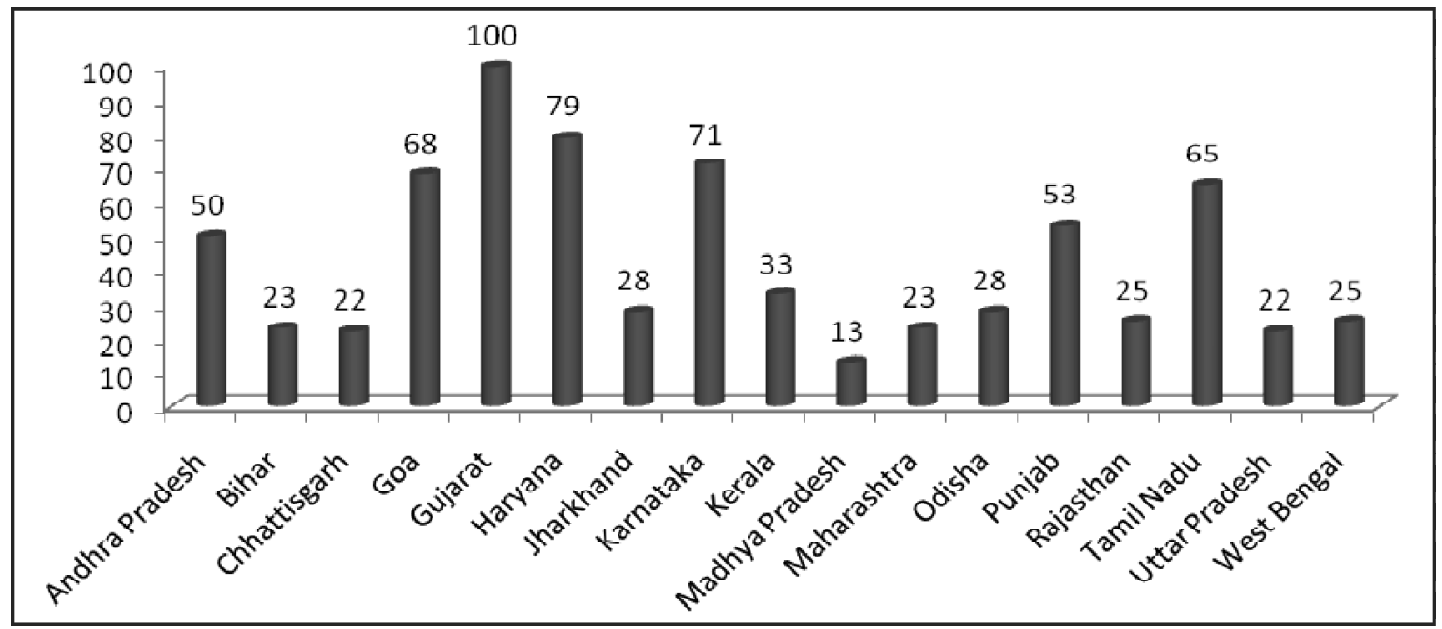

Figure 1: Tax Collection per Rupee Expenditure (General Category States)

Source: Authors' Compilation from RBI (2015)

Figure 1 depicts the ratio measure of efficiency of $\mathrm{GCS}^{1}$ and it is evident from the figure that Gujarat is collecting the highest tax revenue of 100 by spending one Indian rupee on collection followed by Haryana, Karnataka, Goa and Tamil Nadu. Madhya Pradesh is the only general category state where this ratio is below 20. In seven states, tax collection per Indian rupee expenditure is above 50; and in ten states, this ratio value is below 50 .

Ratio measurement of $\mathrm{SCS}^{2}$ is shown in figure 2. It is noticed that on an average, tax collection per Indian rupee expenditure is more in case of GCS in comparison to SCS. The low tax collection per Indian rupee outlay is attributed to geographical conditions. Among SCS, Jammu and Kashmir, Assam, Himachal Pradesh, Tripura and Uttarakhand are in a better position in comparison to Manipur, Meghalaya, Mizoram, Sikkim, Nagaland and Arunachal Pradesh. This is because the former states have ratio value greater than 20 and the latter states have ratio value less than 20. Jammu and Kashmir have the highest ratio value of 26, whereas lowest value is secured by Mizoram. 


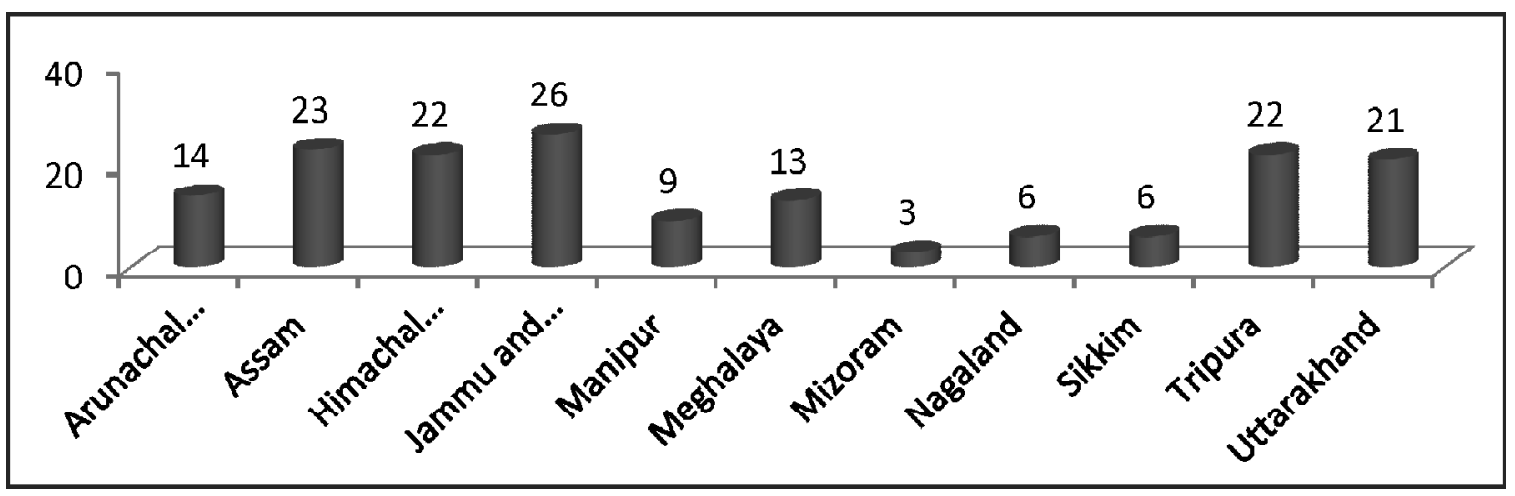

Figure 2: Tax Collection per Rupee Expenditure (Special Category States)

Source: Authors' Compilation from RBI (2015)

Different tax rates in different states and different types of indirect taxes were prevailing before Goods and Services Tax (GST) regime. The Goods and Services Tax (GST) regime has kept aim to bring the unified tax system and improve the tax collection efficiency. In this context, the objective of the study is to find the causes of inefficiency of the tax administration and to prescribe methods/ techniques of increasing the efficiency of tax collection/administration. Data envelopment analysis (DEA) is used in order to measure the relative efficiency of states. The sample period is taken from 2000-2001 to 2016-17 excluding Telangana state. The main findings of this study show that states are 54 percent efficient in collecting their own tax revenue. However, SCS are collecting their own tax revenue with 72 percent efficiency.

\section{Review of Literature}

In the age of intense competition, every private sector agency as well as non-profit organization and public sector agencies are trying to improve its productivity and thereby achieve efficiency by minimizing input with given output or by maximizing output by utilizing same quantities of inputs (Ray and Chen, 2015). However, measuring productive efficiency is not new. Farrell (1957) had started measuring productive efficiency 63 years ago. Even now, interest towards measuring operational efficiency has not been created to that extent in comparison to interest on empirical investigation among economists (Moesen and Persoon, 2002). However, the trend has changed and economists are giving much more importance to the measurement of productive efficiency because of fiscal stress both at the central and regional levels in the $21^{\text {st }}$ century. Generally, research on estimation of efficiency has concentrated on the health sector (Hollingsworth, 2008), education sector (De Witte and López-Torres, 2017) and local services (Narbon-Perpina and De Witte, 2018).

Tax collection is under the purview of public administration and greater importance has been given to collect information regarding how efficiently public administration is doing its job of tax collection. There is limited number of studies related to the measurement of comparative tax collection efficiency across countries. By analyzing those studies, one can come to the conclusion that most of 
the countries are relatively inefficient in "collecting any of the three types of tax revenues, i.e., personal income, corporate income and value-added taxes" (Alm and Dunchan, 2014). "On an average, countries those have achieved average score were able to collect the current level of revenues at 10 to 13 percent lesser inputs" (Aizenman and Jinjarak, 2008).

Fiscal pressure has forced economists in various countries to seriously consider their relative efficiency in tax collection and factors affecting the same. For this reason, studies have been conducted on tax efficiency in Belgium (Moesen and Persoon, 2002), Norway (Forsund, Edvardsen and Kittelsen, 2015), Indonesia (Lewis, 2006), Chile (Serra, 2003), India (Thirtle et al., 2000; Kumar et al., 2007), China (Liu et al., 2013) and Spain (Rubio and Barrilao, 2013; Rubio et al., 2017; Aparicio et al., 2019).

With the passage of time, it has been realized that human capital is the driver of operational efficiency in case of public administration; and offices having good human capital perform better (Liu et al., 2013; Moesen and Persoon, 2002). Also, it is underlined that "local governments with executives are no more cost efficient than those with appointment heads" (Aizenman and Jinjarak, 2008). In one hand, higher grants from national government to provincial government decreases efficiency of tax collection by reducing states revenue effort (Jha et al., 1999 and Panda, 2009) and in the other, increase in the durability in the political regime and regulation of political participation have raised efficiency (Aizenman and Jinjarak, 2008).

Two decades ago, Thritle et al. (2000) and Jha et al. (1999) have measured tax collection efficiency of fifteen Indian states by taking data from 1980-81 to1992-93 using DEA and SFA methods, respectively. The input variables used in these two papers for the measurement of efficiency analysis were "tax collection expenditure as a share of state domestic product (SDP), SDP at constant prices, agriculture share of SDP and poverty index". The use of SDP at constant prices, agricultural share of SDP and poverty index as inputs are misleading the efficiency measurement as these are the factors which describe tax capacity of a state. "Using these inputs results in a special definition of tax efficiency and cannot serve as efficiency index for how the expenditure on tax collection is made for core service tax revenue collection" (Forsund, Edvardsen and Kittelsen, 2015).

\section{Objective of the Study}

In the foregoing discussion, many general questions have been raised like - are Indian states collecting tax efficiently? Or if some of them are inefficient, then how far are they inefficient? What should be done to increase the efficiency of the inefficient states? A question generally asked is - what target must be set before the new tax regime, i.e., GST to achieve full tax collection efficiency?

In this context, the study has aimed to measure tax collection efficiency of Indian states in preGST era and find solutions to tackle inefficiency. Further, the study has extended its objective to prepare a road map for efficiency comparison between pre-GST and post-GST period.

\section{Research Methodology}

\subsection{Data Collection}

Data on literacy rate and percentage of households that experienced corruption have been collected from Census 2011 and Centre for Media Studies (CMS), India Corruption Study 2017. The period of 
the study is taken from 2000-2001 to 2016-17. Data on cost of tax collection (Plan and non-plan) and own tax revenue of Indian states (excluding Telangana ${ }^{3}$ ) are taken as sample in this study.

\subsection{Tools and Techniques}

DEA is used in order to measure the relative efficiency of states, i.e., Decision-Making Units (DMUs). Unlike other methods of efficiency measurement like Stochastic frontier analysis, it does not impose any parametric assumptions on the data and "it can deal with production processes that have multiple inputs and outputs" (Sahoo and Acharya, 2012; Alm and Dunchan, 2014; Acharya and Sahoo, 2017). So, this method is preferred for measuring comparative efficiency of DMUs (Knechel et al., 2009; Mohanty and Sahoo, 2017). Along with that, DEA is also used to measure efficiency where the inlets and outlets are in money terms (Alm and Dunchan, 2014, Rubio and Barrilao, 2013 and Thritle et. al., 2000). Therefore, an input-oriented DEA model with variable returns to scale (VRS) is applied as per the need of the study which assumes output as given and targets proportional input accommodation. The study has used input-oriented DEA model for efficiency measurement because the output i.e., tax revenue depends on so many exogenous variables on which the tax collection agency has no control. Here DEA model with VRS is applied because the relationship of output with inputs and the characteristics of this sector itself assume variable returns to scale.

\subsection{Variables Used}

In this study, efficiency score of 28 Indian states (11 SCS and 17GCS) is measured by considering two inputs and a single output.

Input 1: Ratio of average plan expenditure from 2000-01 to 2016-17 to average Gross State Domestic Product (GSDP) from 2004-05 to 2013-14 of 2004-05 series.

Input 2: Ratio of average non-plan expenditure from 2000-01 to 2016-17 to average GSDP from 2004-05 to 2013-14 of 2004-05 series.

Output 1: Ratio of average own tax revenue from 2000-01 to 2016-17 to average GSDP from 2004-05 to 2013-14 of 2004-05 series.

The study has used 2004-05 series GSDP data instead of 2011-12 series, because for West Bengal, latter series data is not available. The purpose of taking ratio of average own tax revenue to average GSDP, ratio of average plan expenditure to average GSDP and ratio of average non-Plan expenditure to average GSDP instead of average own tax revenue, average plan and average non-plan expenditure of tax collection, is that the former makes the playing field same for all states and makes efficiency analysis more meaningful than the latter. It is because states having more GSDP could collect more tax revenue in comparison to states having less GSDP. For the purpose of performing a cross-sectional analysis, the average of plan, non-plan and tax revenue over years from 2000-01 to 2016-17 is taken into consideration.

\subsection{Fitted Model}

Under the VRS speciation of technology, the input-oriented DEA model of Banker et al., (1984) has been used for estimation of efficiency score of 17 GCS and 11 SCS, by considering two inputs and single output. The set-up of the model used is presented below to compute the efficiency of state o. 
Min $\theta$

Subject to $\Sigma_{d} \lambda_{d} x_{i d}+s_{i}^{-}=\theta_{o} x_{o i} i=1,2$

$$
\begin{aligned}
& \sum_{d} \lambda_{d} y_{d}-s_{r}^{+}=y_{0} \\
& \lambda_{d}, s_{i}^{-}, s_{i}^{+} \geq 0 \quad \forall, i, d \\
& \sum \lambda_{d}=1
\end{aligned}
$$

$X_{d i}=i$ th input used by State $d$

$y_{d}=$ output produced by State $d$

$S_{i}=$ ith input slack

$S_{r}=$ output slack

The above model is run 28 times to compute the efficiency scores of 28 Indian states.

\section{Results and Discussion}

In the modern era, efficiency measurement has become a vital issue. Whether it may be a firm or government organization, everywhere, attaining more output with less input is a matter of concern. In the light of the above discussion, tax collection efficiency is gathering significant attention. Table 1 shows the descriptive statistics of the input and output variables. This can have an ex-ante efficiency

\begin{tabular}{|c|c|c|c|c|c|c|}
\hline & \multicolumn{3}{|c|}{ GCS } & \multicolumn{3}{|c|}{ SCS } \\
\hline & \multirow{2}{*}{$\begin{array}{c}\text { Output } \\
\text { Average own } \\
\text { tax revenue } \\
\text { to GSDP } \\
\text { ratio }\end{array}$} & \multicolumn{2}{|c|}{ Inputs } & \multirow{2}{*}{$\begin{array}{c}\text { Output } \\
\text { Average own tax } \\
\text { revenue to } \\
\text { GSDP ratio }\end{array}$} & \multicolumn{2}{|c|}{ Inputs } \\
\hline & & $\begin{array}{l}\text { Average plan } \\
\text { expenditure to } \\
\text { GSDP ratio }\end{array}$ & $\begin{array}{l}\text { Average Non- } \\
\text { plan expenditure } \\
\text { to GSDP ratio }\end{array}$ & & $\begin{array}{l}\text { Average plan } \\
\text { expenditure to } \\
\text { GSDP ratio }\end{array}$ & $\begin{array}{l}\text { Average Non- } \\
\text { plan } \\
\text { expenditure to } \\
\text { GSDP ratio }\end{array}$ \\
\hline Mean & 0.0909 & 0.00018 & 0.0026 & 0.0510 & 0.00023 & 0.0039 \\
\hline Std. Dev. & 0.0251 & 0.00020 & 0.0016 & 0.0206 & 0.00014 & 0.0023 \\
\hline Maximum & 0.1614 & 0.00079 & 0.0076 & 0.0804 & 0.00048 & 0.0091 \\
\hline Minimum & 0.0589 & 0.00002 & 0.0007 & 0.0224 & 0.00004 & 0.0019 \\
\hline
\end{tabular}
prediction.

Table 1: Summary of Inputs and Outputs

Source: Authors' Calculation

Table 1 reveals that Karnataka might be among the best practice states in general category as it has maximum output and minimum inputs. Similarly, other states such as Haryana and Gujarat are expected to be among best practice states since Haryana has lowest plan expenditure to GSDP and 
Gujarat has minimal average non-plan expenditure to GSDP. In the same way, states having maximal average plan expenditure to GSDP and average non plan expenditure to GSDP might be anticipated to be poor efficiency states in tax collection. For instance, Rajasthan and Madhya Pradesh might be at the bottom rank since the former has maximum average plan expenditure to GSDP and latter has maximum non-plan expenditure to GSDP.

In case of SCS, Jammu and Kashmir and Tripura are expected to be among best practice states in tax collection. It is because the state of Jammu and Kashmir has maximal average tax revenue to GSDP and Tripura has minimal usage of both inputs. In the same fashion, Arunachal and Sikkim might be anticipated to be poor efficient states in tax collection.

For the measurement of relative technical efficiency, input-oriented DEA model is applied by using DEAP computer program version 2.1. Variable returns to scale are assumed while calculating efficiency score through DEA because constant returns to scale assumption is appropriate when DMUs are functioning optimally, but it is hardly possible. Utilization of DEA allows us to determine relative tax collection efficiency of each of the Indian states and to determine degree of efficiency or inefficiency. Here is data on two inputs (average plan expenditure to average GSDP ratio and average non plan expenditure to average GSDP ratio) and one output (average own tax revenue to average GSDP) for 28 states. The efficiency score might be more representative if we have data on total number of employees in hierarchal order along with their education qualification, data on salary cost and information and technology cost. Telangana is not included in the efficiency calculation because it is a newly formed state. Two separate efficiency analyses were performed in which one analysis was for 11 SCS and other for 17 GCS. Two into seventeen input matrix and one into seventeen output matrix represents the data for GCS. Similarly, for calculation of DEA for SCS, the data consists of 11 into 2 input matrix and 11 into 1 output matrix.

The efficiency result of GCS is shown in Table 2. Efficiency score varies between 0 and 1 . Efficiency score of 1 represents the state that is fully efficient and less than 1 represents inefficiency. So, the calculated efficiency score given in the table shows that Gujarat, Haryana and Karnataka are efficient states. For that reason, these fully efficient states are peers or reference states for themselves as well as for inefficient states for achieving efficiency.

Tamil Nadu has efficiency score of 0.819 which has placed the state at rank 2 and suggested that the state could achieve full efficiency by reducing its inputs by 18.1 percent. In ranking of GCS according to efficiency score, Goa is at place 3 followed by Punjab, Andhra Pradesh, West Bengal, Kerala, Maharashtra, Odisha, Jharkhand, and Bihar, which have efficiency score above 0.3. Goa has to reduce its inputs by 28.4 percent for counting itself as efficient state in tax collection. Similarly, Punjab, Andhra Pradesh, West Bengal, Kerala, Maharashtra, Odisha, Jharkhand, and Bihar have to reduce their inputs used for tax collection by 29.8 percent, 34.4 percent, 53.8 per cent, 57.3 percent, 60 percent, 60.3 percent, 63 percent and 67.7 percent, respectively for achieving full efficiency in tax collection. In the process of reduction of inputs, Punjab has to follow Haryana, Gujarat and Karnataka.

Rajasthan, Chhattisgarh, Uttar Pradesh and Madhya Pradesh have efficiency score below 0.3. Among them, Madhya Pradesh is regarded as the most inefficient state having lowest efficiency score of 0.167 and placed at the bottom level in ranking. It was able to collect the same tax revenue to GSDP 
Tax Collection Efficiency of Indian States: A DEA Approach

Table 2: Tax Collection Efficiency Score of GCS

\begin{tabular}{llccc}
\hline N No. & GCS & Efficiency Score & Rank & $\begin{array}{c}\text { Waste of Resources } \\
\text { (in \%) }\end{array}$ \\
\hline 1 & Andhra Pradesh & 0.656 & 5 & 34.4 \\
2 & Bihar & 0.323 & 11 & 67.7 \\
3 & Chhattisgarh & 0.272 & 13 & 72.8 \\
4 & Goa & 0.716 & 3 & 28.4 \\
5 & Gujarat & 1 & 1 & 0 \\
6 & Haryana & 1 & 1 & 0 \\
7 & Jharkhand & 0.370 & 1 & 63 \\
8 & Karnataka & 1 & 7 & 0 \\
9 & Kerala & 0.427 & 15 & 57.3 \\
10 & Madhya Pradesh & 0.167 & 8 & 83.3 \\
11 & Maharashtra & 0.400 & 9 & 60.3 \\
12 & Odisha & 0.397 & 12 & 29.8 \\
13 & Punjab & 0.702 & 2 & 72 \\
14 & Rajasthan & 0.280 & 14 & 18.1 \\
15 & Tamil Nadu & 0.819 & 6 & 77.1 \\
16 & Uttar Pradesh & 0.229 & & 53.8 \\
17 & West Bengal & 0.462 & & 45.8 \\
\hline
\end{tabular}

Source: Authors' Calculation

ratio by reducing plan and non-plan expenditure to GSDP by 83.3 percent. On average, efficiency score of all general states is 0.542 , which means general states on average are able to reduce their inputs by 45.8 percent. Ten states have efficiency score less than 0.5 out of which four states have efficiency score less than 0.3 . Only four states have efficiency score more than 0.5 but less than 1 and three states have efficiency score equal to 1 . Inefficient states need to reduce their inputs to be considered as efficient in tax collection, and in the process of input reduction, they are advised to refer to efficient states. The reference states and weights of efficient states as a peer state for inefficient ones are provided in Table 3. In the process of reduction of inputs, the reference states for Andhra Pradesh, Chhattisgarh, Kerala, Tamil Nadu and Uttar Pradesh are Gujarat, Karnataka and Haryana. Similarly, Haryana and Gujarat are the reference states for Bihar, Goa, Jharkhand, Odisha, Punjab and West Bengal. Madhya Pradesh needs to follow Karnataka and Haryana as reference states. As per Table 3, Haryana has been a peer state for inefficient states for thirteen times, whereas Gujarat has been counted twelve times and Karnataka six times as a reference state for inefficient states. Weight value signifies the importance of peer states for the inefficient ones. 
Pitabas Biswal and Himanshu Sekhar Rout

Table 3: Reference States and their Weights for GCS

\begin{tabular}{|c|c|c|c|c|c|c|c|c|}
\hline SNo. & State Name & Rank & Ref 1 & $\begin{array}{r}\text { Weight of } \\
\text { Ref } 1\end{array}$ & Ref 2 & $\begin{array}{r}\text { Weight of } \\
\text { Ref } 2\end{array}$ & Ref 3 & $\begin{array}{r}\text { Weight of } \\
\text { Ref } 3\end{array}$ \\
\hline 1 & Andhra Pradesh & 5 & Haryana & 0.187 & Gujarat & 0.149 & Karnataka & 0.664 \\
\hline 2 & Bihar & 11 & Haryana & 0.509 & Gujarat & 0.491 & & \\
\hline 3 & Chhattisgarh & 13 & Gujarat & 0.265 & Karnataka & 0.111 & Haryana & 0.624 \\
\hline 4 & Goa & 3 & Gujarat & 0.782 & Haryana & 0.218 & & \\
\hline 5 & Gujarat & 1 & Gujarat & 1 & & & & \\
\hline 6 & Haryana & 1 & Haryana & 1 & & & & \\
\hline 7 & Jharkhand & 10 & Haryana & 0.1 & Gujarat & 0.9 & & \\
\hline 8 & Karnataka & 1 & Karnataka & 1 & & & & \\
\hline 9 & Kerala & 7 & Haryana & 0.771 & Gujarat & 0.076 & Karnataka & 0.153 \\
\hline 10 & Madhya Pradesh & 15 & Karnataka & 0.146 & Haryana & 0.854 & & \\
\hline 11 & Maharashtra & 8 & Haryana & 1 & & & & \\
\hline 12 & Odisha & 9 & Haryana & 0.634 & Gujarat & 0.366 & & \\
\hline 13 & Punjab & 4 & Haryana & 0.884 & Gujarat & 0.116 & & \\
\hline 14 & Rajasthan & 12 & Gujarat & 1 & & & & \\
\hline 15 & Tamil Nadu & 2 & Haryana & 0.674 & Gujarat & 0.098 & Karnataka & 0.228 \\
\hline 16 & Uttar Pradesh & 14 & Gujarat & 0.658 & Karnataka & 0.032 & Haryana & 0.31 \\
\hline 17 & West Bengal & 6 & Haryana & 0.905 & Gujarat & 0.095 & & \\
\hline
\end{tabular}

Source: Authors' Calculation

After such a close look into the efficiency analysis of GCS; it is time to have a discussion regarding SCS. The efficiency result is shown in Table 4.

Table 4: Tax Collection Efficiency of SCS

\begin{tabular}{|c|c|c|c|c|}
\hline SlNo & SCS & Efficiency score & Rank & Waste of Resources (in \%) \\
\hline 1 & Arunachal Pradesh & 0.950 & 2 & 5 \\
\hline 2 & Assam & 0.938 & 3 & 6.2 \\
\hline 3 & Himachal Pradesh & 0.893 & 4 & 10.7 \\
\hline 4 & Jammu and Kashmir & 1 & 1 & 0 \\
\hline 5 & Manipur & 0.514 & 8 & 48.6 \\
\hline 6 & Meghalaya & 0.573 & 7 & 42.7 \\
\hline 7 & Mizoram & 0.247 & 10 & 75.3 \\
\hline 8 & Nagaland & 0.613 & 6 & 38.7 \\
\hline 9 & Sikkim & 0.351 & 9 & 64.9 \\
\hline 10 & Tripura & 1 & 1 & 0 \\
\hline \multirow[t]{2}{*}{11} & Uttarakhand & 0.852 & 5 & 14.8 \\
\hline & Average & 0.721 & & 27.9 \\
\hline
\end{tabular}

Source: Authors' Calculation 
Jammu and Kashmir and Tripura are efficient in the sense that their relative efficiency score is equal to one. The efficiency scores of Arunachal Pradesh and Assam are above 0.9 which has placed those states at second and third places, respectively in ranking of states according to efficiency score. Mizoram has the lowest efficiency score of 0.247 followed by Sikkim, Manipur, Meghalaya and Nagaland. Nine SCS have relative efficiency score greater than 0.5 . For that reason, mean efficiency score of SCS is 0.721 . The tax collection efficiency score of SCS has provided a road map for improvement. Jammu and Kashmir and Tripura are the reference states for themselves as their efficiency score is equal to one. Arunachal Pradesh is in need of improving its efficiency score by reducing inputs by 5 percent. In the process of reduction of inputs, Arunachal Pradesh is advised to refer to Tripura. Similarly, Mizoram, Sikkim, Manipur, Meghalaya and Nagaland are advised to reduce their inputs by 75.3 percent, 64.9 percent, 48.6 percent, 42.7 percent and 38.7 percent, respectively. Assam and Himachal Pradesh are in need of reducing their inputs by 6.2 and 10.7 percent, respectively (Table 5).

Table 5: Reference States and their Weights for SCS

\begin{tabular}{llrlrrr}
\hline SNo. & SCS & Rank & Ref 1 & $\begin{array}{r}\text { Weight } \\
\text { of Ref 1 }\end{array}$ & Ref 2 & $\begin{array}{r}\text { Weight of } \\
\text { Ref 2 }\end{array}$ \\
\hline 1 & Arunachal Pradesh & 2 & Tripura & 1 & & \\
2 & Assam & 3 & Jammu and Kashmir & 0.633 & Tripura & 0.367 \\
3 & Himachal Pradesh & 4 & Jammu and Kashmir & 0.779 & Tripura & 0.221 \\
4 & Jammu and Kashmir & 1 & Jammu and Kashmir & 1 & & \\
5 & Manipur & 8 & Tripura & 1 & & \\
6 & Meghalaya & 7 & Jammu and Kashmir & 0.047 & Tripura & 0.953 \\
7 & Mizoram & 10 & Tripura & 1 & & \\
8 & Nagaland & 6 & Tripura & 1 & & \\
9 & Sikkim & 9 & Jammu and Kashmir & 0.431 & Tripura & 0.569 \\
10 & Tripura & 1 & Tripura & 1 & & \\
11 & Uttarakhand & 5 & Jammu and Kashmir & 0.826 & Tripura & 0.174 \\
\hline
\end{tabular}

Source: Authors'Calculation

In reducing inputs by the said percentage for achieving fully efficiency, Himachal Pradesh needs to follow Jammu and Kashmir and Tripura with weights 0.779 and 0.221 , respectively. Nagaland, Manipur, Mizoram and Arunachal Pradesh should refer to Tripura for reducing inputs. In the same way, Mizoram is advised to follow Arunachal Pradesh and Tripura. It can be noticed from table 5 that Jammu and Kashmir is counted four times as a peer unit for another, whereas Tripura is counted 10 times as a peer unit for another. Karl Pearson's correlation technique is used to establish the degree and extent of relationship between efficiency score and tax collection per rupee expenditure. The result is shown in Table 6. 
Pitabas Biswal and Himanshu Sekhar Rout

Table 6: Correlation Between Efficiency Score and Tax Collection Per Rupee Expenditure

\begin{tabular}{lcc}
\hline States & GCS & SCS \\
\hline Correlation Coefficient( $\mathrm{r})$ & 0.959 & 0.903 \\
Significance level & 0.01 & 0.01 \\
\hline
\end{tabular}

Source: Authors' Calculation

The correlation coefficient between efficiency score and own tax per expenditure is 0.903 and correlation is significant at the 0.01 level in case of SCS. The result of efficiency score has a correlation of 0.959 with tax revenue and collection expenditure ratio and this correlation coefficient is significant at 0.01 level. So, it is clear that those states having either less collection expenditure or high tax revenue or both have high efficiency score. Shagaria and Saad (2017) and Shojaee (2016) highlighted that the tax collection efficiency score is positively correlated with use of information and communication technology (particularly use of computers and other electronic gadgets), public enlightenment, motivation and incentives; and corruption negatively affects tax collection efficiency. However, in the Indian context, data on use of communication and technology and incentives and motivation given by each state are not available. So, the study has tried to find whether the relationship between public awareness and corruption with efficiency score in the Indian context is telling the same story.

In this study, literacy rate is used as a proxy for public awareness with the assumption that more literacy leads to greater public awareness. State-wise corruption perception index score is not available; so, percentage of 'households that experienced corruption in public service' is used to determine the correlation with efficiency score. Here non-SCS are taken into consideration because 'households that experienced corruption' data are available for GCS. It is evident from Table 7 that moderate correlation exists between efficiency score and literacy rate and also the coefficient value is statistically significant at five percent level of significance. In case of correlation of efficiency score with percentage of households that experienced corruption, the correlation coefficient is negative but it is very low. Use of information and communication technology promotes transparency in tackling corruption in one hand (Serrat, 2017); and on the other, Introduction of tax education at school level might enhance public awareness like Environmental study in high school and college level creates awareness about environment (Sola, 2014) so, the study suggests more and more use of information and communication technology for checking corruption and introduction of Tax education at high school level for public awareness.

Table 7: Correlation Coefficient of Efficiency Score with Literacy Rate and Percentage of Households Experienced Corruption

\begin{tabular}{lcc}
\hline & Correlation coefficient & Significance level $(\alpha)$ \\
\hline $\begin{array}{l}\text { Correlation between efficiency score and literacy rate } \\
\text { Correlation between efficiency score and percentage }\end{array}$ & 0.584 & 0.05 \\
of households experienced corruption & -0.209 & 0.05 \\
\hline
\end{tabular}

Source: Authors' Calculation 


\section{Conclusion}

The study has attempted to know whether Indian states are collecting taxes efficiently by using DEA. For the analysis, all Indian states were classified into two categories: general states and special states. General states have mean relative efficiency score equal to 0.542 , meaning the states are 54 percent efficient in collecting their own tax revenue. However, SCS are collecting their own tax revenue with 72 percent efficiency. Therefore, GCS and SCS could collect the same tax revenue to GSDP by using 46 percent and 28 percent lesser inputs, respectively.

Although tax collection inefficiency is the reality in case of Indian states, achievement of full efficiency is not a myth. A tax reformation was barely required. However, GST as a reformation of indirect taxes has been implemented in India since July 2017. So, this study sets a target before the new tax regime to achieve hundred percent efficiency in use of inputs by increasing own tax revenue to GSDP or by reducing tax collection expenditure to GSDP or by both increasing own tax revenue to GSDP and reducing tax collection expenditure to GSDP. In the presence of reforms, public awareness and incentives to honest tax payers, rampant use of ICT for reduction of corruption and introduction of Tax education at high school level are barely required for the enhancement of efficiency in tax collection.

\section{Notes}

1. GCS: Andhra Pradesh, Bihar, Chhattisgarh, Goa, Gujarat, Haryana, Jharkhand, Karnataka, Kerala, Madhya Pradesh, Maharashtra, Odisha, Punjab, Rajasthan, Tamil Nadu, Uttar Pradesh, West Bengal.

2. SCS: Arunachal Pradesh, Assam, Himachal Pradesh, Jammu and Kashmir, Manipur, Meghalaya, Mizoram, Nagaland, Sikkim, Tripura, and Uttarakhand.

3. Data is unavailable since Telangana State was formed in 2014.

\section{References}

Acharya, D. and Sahoo, B. K. (2017). Dynamic Macroeconomic Performance of Indian States: Some Post Reform Evidence, In A. Batabyal and Peter Nijkamp (eds.), Regional Growth and Sustainable Development in Asia (Chapter 9, pp. 181-197), New Frontiers in Regional Science: Asian Perspectives 7, Switzerland: Springer.

Aizenman, J. and Jinjarak, Y. (2008). The Collection Efficiency of the Value Added Tax: Theory and International Evidence, The Journal of International Trade and Economic Development, 17(3), 391-410.

Alm, J. and Dunchan, D. (2014). Estimating Tax Agency Efficiency. Public Budgeting and Finance, 34(3), 92 - 110.

Aparicio, J., Cordero, J. M. and Díaz Caro, C. (2019). Efficiency and Productivity Change of Regional Tax Offices in Spain: An Empirical Study Using Malmquist-Luenberger and Luenberger indices, Empirical Economics, https://doi.org/10.1007/s00181-019-01667-8

Banker, R.D., Charnes, A. and Cooper, W.W. (1984). Some Models for Estimating Technical and Scale Inefficiencies in Data Envelopment Analysis, Management Science, 30(9), 1078-1092.

Chiumia, A. and Simwake, K. (2012). Tax Policy Developments, Donor Inflows and Economic Growth in Malawi, Journal of Economics and International Finance, 4(7), 159-172.

De Witte, K. and López-Torres, L. (2017). Efficiency in Education. A Review of Literature and a Way Forward, Journal of the Operational Research Society, 68(4), 339-363. 
Farrell, M. J. (1957). The Measurement of Productive Efficiency, Journal of the Royal Statistical Society, 120(3), 253281.

Forsund, F.R., Edvardsen, D. F. and Kittelsen, S. A. C. (2015). Productivity of tax offices in Norway, Journal of Productivity Analysis, 43(3), 269-279.

Hollingsworth, B. (2008). The Measurement of Efficiency and Productivity of Healthcare Delivery, Health Economics, 17(10),1107-1128

Jha, R., Mohanty, M., Chatterjee, S. and Chitkara, P. (1999). Tax Efficiency in Selected Indian States, Empirical Economics. 24(4),641-654.

Knechel, W. R., Rouse, P. and Schelleman, C. (2009). A Modified Audit Production Framework: Evaluating the Relative Efficiency of Audit Engagements, The Accounting Review, 84(5), 1607-1638

Kumar, A. and Panda, P. K. (2016). Estimation of tax buoyancy among Indian states: a comparative analysis of pre- and post-VAT period, Journal of Economic Policy and Research, 11(2), 4-12

Kumar, S., Nagar, A. L. and Samanta, S. (2007). Indexing the Effectiveness of Tax Administration, Economic and Political Weekly, 42(50),104-110.

Lewis, B. D. (2006). Local Government Taxation: An Analysis of Administrative Cost Inefficiency, Bulletin of Indonesian Economic Studies, 42(2),213-233.

Liu, H., Zhou, Q., Zhou, L. and Wang, S. (2013). On the Human Capital Factors to Evaluate the Efficiency of Tax Collection using Data Envelopment Analysis, Research Journal of Applied Sciences, Engineering and Technology, 5(6),2156-2162.

Moesen, W. and Persoon, A. (2002). Measuring and Explaining the Productive Efficiency of Tax Offices: A Non-parametric Best Practice Frontier Approach, Review of Business and Economics, 10(3), 399-416.

Mohanty, R. K. and Sahoo, B.K. (2017). Examining the Eco-macroeconomic Performance Index of India: A Data Envelopment Analysis, Working Paper 202, National Institute of Public Finance and Policy, New Delhi.

Narbon-Perpina, I. and De Witte, K. (2018). Local Governments' Efficiency: A Systematic Literature Review Part I, International Transaction in Operational Research, 25(2),431-468.

Panda, P. K. (2009). Central Fiscal Transfers and States' Own Revenue Efforts in India: Panel Data Models, The Journal of Applied Economic Research, 3(3),223-242

Ray, S. C. and Chen, L. (2015). Data Envelopment Analysis for Performance Evaluation: A Child's Guide, In: Ray, S., Kumbhakar, S., and Dua, P. (Eds.) Benchmarking for Performance Evaluation, Springer, New Delhi, Pp. 75-116.

RBI (2015). State Finances: A Study from Budget, Reserve Bank of India, Mumbai.

Rubio, E. and Barrilao, P. (2013). The Efficiency of the Regional Management Centers of the Tax Administration in Spain, Journal of US-China Public Administration, 10(1), 49-56.

Rubio, E. V., González, P. E. B., and Alaminos, J. D. (2017). Relative Efficiency within a Tax Administration: The Effects of Result Improvement, Finance Political Economy, 9(1), 135-149.

Sahoo, B. K., and Acharya, D. (2012). Constructing Macroeconomic Performance Index of Indian States Using DEA, Journal of Economic Studies, 39(1), 63-83.

Serra, P. (2003). Measuring the Performance of Chile's Tax Administration, National Tax journal, 56(2), 373-383.

Serrat, O. (2017). Fighting Corruption with ICT: Strengthening Civil Society's Role, In Haidy Ear-Dupuy and Olivier Serrat (Eds.) Knowledge Solution. Springer, Singapore, Pp. 797-811. 
Tax Collection Efficiency of Indian States: A DEA Approach

Shagaria, S. L. and Saad, N. (2017). Critical Success Factors to Tax Administration Efficiency in Nigeria: Evidence from Bauchi State Board on Internal Revenue, Available at http:// mmj.uum.edu.my/images/vol21 dec17/ criticalsuccess-factors-to-tax-administration-efficiency-in-nigeria.pdf accessed on 5 June 2018.

Shojaee, T. (2016). Factors Affecting the Efficiency of the Tax System from the Perspective of Tax Experts of Tehran City Tax Affairs, International Journal of Humanities and Cultural Studies, 3(Special Issue), 18831893.

Sola, A. O. (2014). Environmental Awareness and Public Education, Journal of Education and Social Research, 4(3), 333-337.

Thirtle, C., Shankar, B., Chitkara, P., Chatterjee, S. and Mohanty, M. S. (2000). Size Does Matter: Technical and Scale Efficiency in Indian State Tax Jurisdictions, Review of Development Economics, 4(3), 340-352.

Toro, J., Jensen, A., Thakray, M., Kidd, M. and Russell, B. (2015). Tax Administration Modernization Challenges and Strategic Priorities, IMF Country Report, No-15/112, Washington DC.

Orissa Journal of Commerce, 42(1) (C) 2021 